\title{
Body Dysmorphic Disorder di Layanan Estetik: Prevalensi, Problematika, dan Deteksi Dini
}

\author{
Agustini Song ${ }^{1}$, Mahaputra ${ }^{2}$ \\ ${ }^{1}$ Rumah Sakit Umum Daerah S.K. Lerik, Kota Kupang, Nusa Tenggara Timur, Indonesia \\ ${ }^{2}$ Fakultas Kedokteran dan Ilmu Kesehatan Universitas Katolik Indonesia Atma Jaya, Jakarta, \\ Indonesia \\ Alamat Korespondensi: agustinisong@gmail.com
}

\begin{abstract}
Abstrak
Body Dysmorphic Disorder (BDD) merupakan salah satu gangguan jiwa dengan prevalensi yang bermakna namun seringkali tidak terdiagnosis. Orang dengan BDD sering datang ke layanan estetik untuk merubah penampilan mereka melalui tindakan operasi. Hingga saat ini belum ada data atau literatur mengenai BDD di layanan estetik di Indonesia. Tujuan tulisan ini adalah membahas mengenai prevalensi BDD di layanan estetik, problematika yang dihadapi oleh dokter layanan estetik, dan deteksi dini BDD di layanan estetik. Metode penelusuran dengan pencarian pustaka yang relevan secara online. Prevalensi BDD di layanan estetik lebih besar daripada populasi umum karena mayoritas orang dengan BDD mencari pengobatan ke layanan non-psikiatri seperti klinik bedah plastik estetik dan dermatologi. Di sisi lain, kesadaran dokter layanan estetik terhadap klien dengan BDD masih rendah dan masih terdapat perbedaan pendapat mengenai BDD sebagai kontraindikasi tindakan operasi. Tindakan operasi pada klien dengan BDD berpotensi memperburuk BDD dan menyebabkan ancaman terhadap dokter yang menangani, seperti gugatan legal bahkan pembunuhan. Deteksi dini BDD di layanan estetik dapat dilakukan dengan alat skrining BDD dan dilanjutkan dengan rujukan ke layanan psikiatri. Kesadaran dan deteksi dini BDD di layanan estetik krusial agar orang dengan BDD mendapatkan penanganan psikiatri yang dibutuhkan dan risiko masalah legal bagi dokter yang menangani dapat dikurangi.
\end{abstract}

Kata Kunci: body dysmorphic disorder, estetik, psikiatri, skrining

\section{Body Dysmorphic Disorder at Aesthetic Setting: Prevalence, Challenge, and Early Detection}

\begin{abstract}
Body Dysmorphic Disorder (BDD) is one of mental disorders with significant prevalence but is frequently undiagnosed. People with BDD often come to aesthetic setting to modify their appearance surgically. There is no data or literature about BDD at aesthetic setting in Indonesia. This paper aims to discuss about BDD prevalence in aesthetic setting, challenge for the physician in charge, and early detection of BDD in aesthetic setting. Our method is online relevant literature searching. Prevalence of BDD in aesthetic setting is higher than general population because majority of people with BDD seek treatment to non-psychiatry setting, like aesthetic plastic surgery and dermatology clinic. Meanwhile, aesthetic setting physician's awareness of client with BDD is still low and whether BDD is surgery contraindication is still debatable. Any surgical treatment for client with BDD has potential to worsen the BDD and inflict threat for the physician, including lawsuit or even murder. BDD early detection can be conducted by BDD screening tool, and continued to psychiatry referral. Awareness and early detection of BDD in aesthetic setting is crucial in order to get people with BDD the necessary psychiatric treatment and reduce the legal issue risk for the physician in charge.
\end{abstract}

Keywords: aesthetic, body dysmorphic disorder, psychiatry, screening 


\section{Pendahuluan}

Body Dysmorphic Disorder (BDD) adalah sebuah gangguan psikiatri yang ditandai dengan adanya preokupasi defek atau ketidaksempurnaan tubuh yang sebenarnya tidak terlalu disadari oleh orang lain yang menyebabkan munculnya perilaku seperti mengecek penampilan berkali-kali atau sering membandingkan penampilan diri dengan orang lain. ${ }^{1}$ Orang dengan BDD biasanya sulit untuk menekan atau mengalihkan preokupasi tersebut dan baru bisa hilang atau berkurang apabila melakukan tindakan tertentu, seperti menutupi wajah atau mengubah bentuk wajah sehingga menjadi tekanan tersendiri untuk dirinya. ${ }^{1,2}$ Prevalensi BDD di dunia, menurut data dari International OCD Foundation dan beberapa jurnal adalah 1,7-2,9\% dari populasi, atau sekitar 1 dari setiap 50 orang. ${ }^{3-8}$ Penelitian lain menyebutkan bahwa prevalensi BDD di beberapa negara adalah sekitar $0,7-2,4 \% .^{3,4,9-11}$ Menurut penelitian-penelitian yang sudah ada, ternyata prevalensi BDD lebih tinggi bila dibandingkan dengan gangguan jiwa lain seperti obsessivecompulsive disorder (OCD), gangguan skizofrenia, dan anoreksia nervosa. ${ }^{1,7,12-14}$ BDD juga dilaporkan ditemukan pada rentang usia mulai dari 5 tahun hingga 80 tahun, ${ }^{15}$ dengan kecenderungan lebih

banyak pada perempuan. ${ }^{3,4,11}$ Terdapat kemungkinan angka prevalensi BDD yang sebenarnya lebih besar dari yang diperkirakan karena banyak orang dengan BDD merasa malu untuk menceritakan gejala mereka kepada orang lain sehingga tidak terdiagnosis oleh tenaga medis. ${ }^{16}$

Suatu studi potong lintang pada tahun 2019 menemukan bahwa terdapat peningkatan prevalensi BDD pada populasi remaja, ${ }^{17}$ yang diduga berkaitan dengan meningkatnya penggunaan media sosial dan menurunnya kepuasan terhadap citra tubuh (persepsi seseorang terhadap tampilan fisik tubuhnya sendiri). ${ }^{18,19}$ Penggunaan media sosial diduga berpengaruh terutama yang bersifat pasif dan berfokus pada penampilan. Penggunaan yang pasif adalah penggunaan media sosial yang hanya bertujuan untuk melihat postingan pengguna lain tanpa terlibat aktif, sedangkan berfokus pada penampilan berarti lebih memperhatikan perbandingan antara tampilan diri dengan orang lain. Tingginya frekuensi penggunaan dalam membandingkan penampilan pengguna dengan pengguna lain dapat memfasilitasi perkembangan dan mempertahankan gejala BDD. ${ }^{19}$ Durasi dan frekuensi menggunakan media sosial juga merupakan faktor risiko BDD dan kecenderungan membandingkan diri dengan orang lain dapat menjadi cikal bakal manifestasi klinis BDD. ${ }^{19}$

Pandemi COVID-19 yang telah berlangsung setahun terakhir ini menyebabkan banyak pembatasan, seperti karantina mandiri dan menetap di rumah. Hal ini menyebabkan peningkatan stres dan kecemasan terutama pada orang dengan BDD. Apabila orang tersebut berkomorbid dengan gangguan depresif, kecenderungan untuk bunuh diri akibat perasaan tidak berdaya dan tidak berharga dapat meningkat. ${ }^{20}$ Selain itu, meningkatnya penggunaan panggilan video dan konferensi video dalam berkomunikasi dan melaksanakan berbagai kegiatan berpotensi menyebabkan pengguna mengalami preokupasi terhadap ketidaksempurnaan penampilan seperti kerutan wajah atau jerawat akibat peningkatan frekuensi melihat diri sendiri. ${ }^{21} \mathrm{Di}$ sisi lain, pandemi mungkin membuat akses ke pelayanan estetik lebih terbatas sehingga mencegah orang dengan BDD untuk secara kompulsif mengubah penampilannya. $^{20}$

Prevalensi BDD di Indonesia di populasi umum tidak diketahui secara jelas, tetapi diperkirakan berjumlah cukup banyak apabila melihat prevalensi secara global. Oleh karena sedikitnya informasi mengenai BDD di Indonesia, terutama di layanan estetik, maka tinjauan pustaka ini dibuat untuk membahas mengenai prevalensi BDD di layanan estetik, problematika yang dihadapi oleh dokter layanan estetik, dan deteksi dini BDD di layanan estetik.

\section{Kriteria Diagnosis BDD}

Secara klinis, seseorang tergolong sebagai orang dengan BDD bila memenuhi kriteria diagnosis yang dinilai dengan pemeriksaan oleh seorang ahli baik psikiater maupun psikolog klinis. Kriteria diagnosis BDD menurut DSM-5 ditampilkan pada tabel 1 . 


\section{Tabel 1. Kriteria Diagnosis BDD ${ }^{1}$}

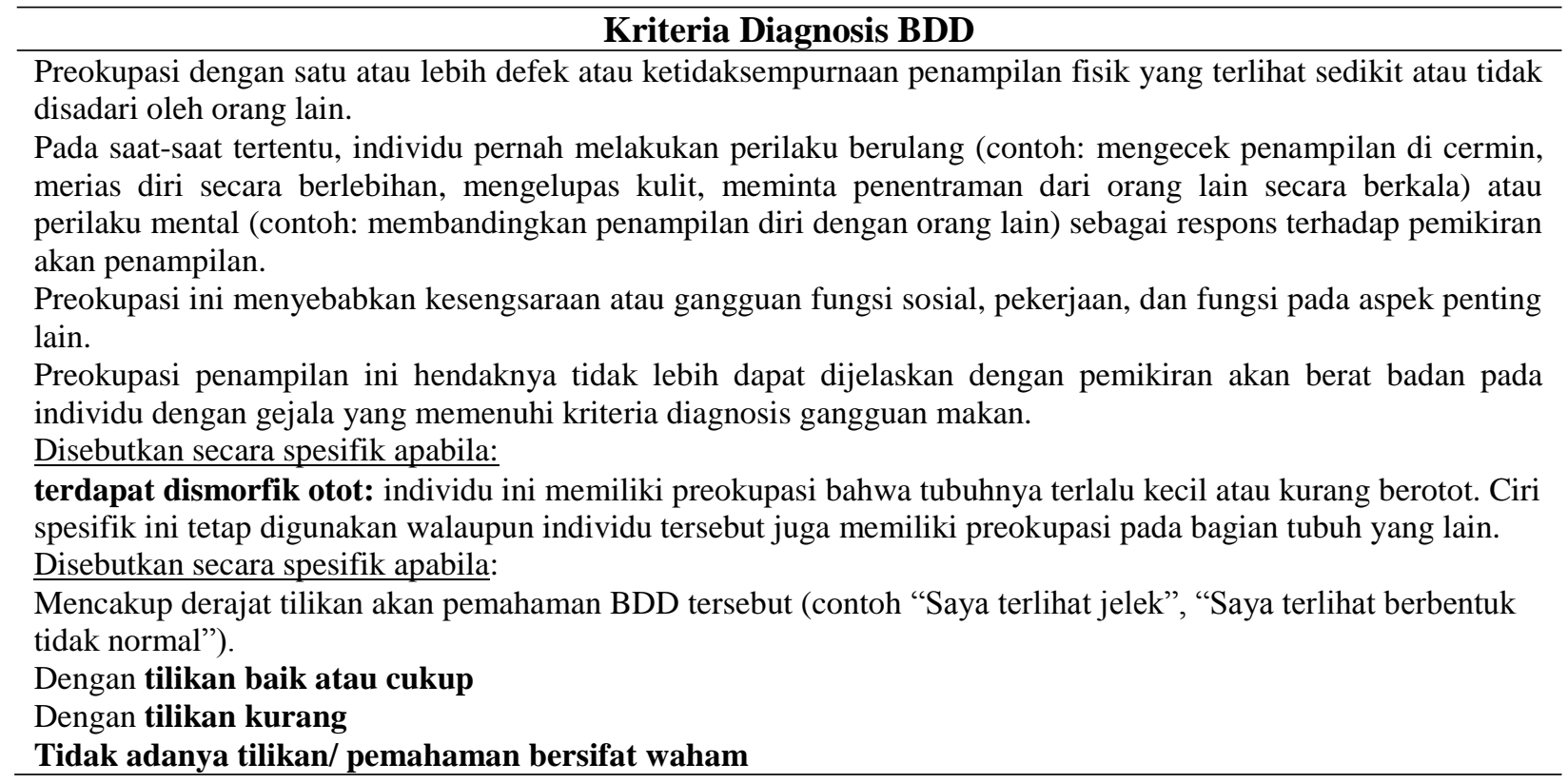

\section{Dampak BDD}

Kelainan BDD memiliki beberapa dampak mental maupun fisik. Orang dengan BDD cenderung akan menyendiri karena menghindari orang yang dipersepsikan akan memiliki pandangan buruk mengenai penampilan dirinya. ${ }^{2}$ Hal ini disebabkan oleh tingginya sensitivitas orang dengan BDD terhadap penolakan oleh orang lain.,15 Kecemasan yang sangat tinggi terkait penolakan ini membuat orang dengan BDD menghindari interaksi dengan orang lain walaupun sebenarnya ia sangat membutuhkan validasi psikis oleh orang tersebut. ${ }^{22,23}$

Dampak lainnya adalah orang dengan BDD cenderung lebih mudah mengalami gangguan depresif atau gangguan cemas. ${ }^{8,24}$ Dampak yang terakhir adalah orang dengan BDD cenderung akan melakukan segala cara yang ia percayai dapat memperbaiki bagian tubuh yang dianggap "jelek". Upaya berlebih seperti sering ke salon kecantikan dan melakukan modifikasi tubuh, dapat menyebabkan dampak lain seperti masalah ekonomi atau ketidakpuasan psikis. $^{15}$ Pada dasarnya BDD disebabkan oleh isu psikis dalam diri yang mengganggu sehingga mengubah tampilan eksternal dengan kosmetik atau modifikasi bentuk tubuh, kurang bisa memuaskan klien. Hal ini dapat berujung pada tuntutan atau komplain terhadap pemberi jasa estetik yang bersangkutan. ${ }^{25}$

\section{Prevalensi BDD pada Layanan Estetik}

Meskipun BDD merupakan masalah kesehatan di bidang psikiatri, seringkali orang dengan BDD tidak memiliki tilikan yang baik dan merasa bahwa solusi untuk masalah yang mereka hadapi adalah melalui upaya untuk "memperbaiki" bagian tubuh yang mereka tidak sukai. Terdapat beberapa penelitian yang menunjukkan bahwa $71-76 \%$ orang dengan BDD mencari pengobatan ke layanan nonpsikiatri seperti klinik bedah plastik estetik, dermatologi, dan gigi. ${ }^{26,27}$ Prosedur estetik yang paling sering mereka lakukan adalah mengubah hidung, kulit, rambut, dagu, dan telinga, yang biasanya dilakukan oleh dokter bedah plastik estetik dan dokter spesialis kulit, sehingga kedua spesialisasi ini merupakan bagian yang paling sering terpapar oleh orang dengan BDD. ${ }^{26-28}$ Penelitian pada layanan klinik bedah plastik fasial dan rekonstruktif menemukan $13,1 \%$ klien yang menjalani bedah estetik memiliki BDD. ${ }^{29}$ Telaah sistematis dan meta analisis oleh Ribeiro (2017) juga menemukan bahwa $15,04 \%$ dari klien bedah plastik memiliki BDD, dan 12,65\% klien dermatologi mengalami BDD. ${ }^{30}$ Suatu telaah sistematis menemukan bahwa $20,1 \%$ dari orang yang menjalani prosedur rhinoplasty merupakan orang dengan BDD, diikuti oleh $13,2 \%$ pada prosedur bedah estetik umum, dan 11,3\% pada layanan rawat jalan kulit, namun hanya $5,8-7,4 \%$ pada layanan psikiatri. ${ }^{6}$ Bahkan studi oleh Vindigni dkk (2002) menemukan sebanyak 53,6\% klien 
yang datang ke layanan estetik merupakan orang dengan BDD. ${ }^{31}$

Hal ini menunjukkan bahwa prevalensi klien dengan BDD di layanan prosedur estetik lebih tinggi dibandingkan di layanan psikiatri dan populasi umum. Di Indonesia sendiri, prevalensi orang dengan BDD yang datang ke layanan prosedur estetik masih tidak diketahui dengan jelas. Diperkirakan seiring bertambahnya layanan prosedur estetik di Indonesia, kemungkinan seorang dokter layanan estetik bertemu klien dengan BDD meningkat.

\section{Dampak Negatif Prosedur Estetik pada BDD}

Salah satu studi menemukan lebih dari 95\% orang dengan BDD melaporkan tidak ada perbaikan, bahkan terdapat perburukan derajat keparahan BDD mereka setelah menjalani prosedur estetik. ${ }^{26,32}$ Terdapat empat penelitian yang menemukan adanya peningkatan risiko bunuh diri yang lebih tinggi sebesar 2-3 kali pada perempuan dengan implant payudara dibandingkan perempuan populasi umum. $^{33}$ Meskipun bunuh diri belum bisa dinyatakan sebagai efek samping dari BDD, prosedur estetik yang dilakukan, ataupun faktor lain, namun dari perspektif klinis, prosedur estetik dapat memberikan ekspektasi bagi orang dengan BDD, dan ketika ekspektasi ini tidak terpenuhi maka mereka dapat menjadi lebih rentan melakukan bunuh diri. $^{32}$ Meskipun 33\% orang dengan BDD yang mendapatkan tindakan operasi atau tindakan invasif minimal mengatakan terdapat perbaikan penampilan dan $25 \%$ melaporkan pengurangan preokupasi, 97,7\% melaporkan tidak ada perbaikan atau malah perburukan dari gejala BDD, termasuk gangguan dalam fungsi sehari-hari. ${ }^{34}$ Kualitas hidup orang dengan BDD juga cenderung tidak mengalami perbaikan setelah prosedur, seperti yang ditunjukkan di beberapa penelitian. ${ }^{35}$

Dalam suatu survei yang melibatkan 265 dokter bedah estetik, 29\% melaporkan bahwa mereka pernah dituntut oleh klien dengan $\mathrm{BDD}$, dan $2 \%$ dari mereka melaporkan pernah diancam secara fisik. ${ }^{36}$ Sampai saat ini sudah ada tiga kasus pembunuhan dokter bedah oleh klien yang memiliki gejala BDD. ${ }^{32,37-40}$ Survei yang dilakukan pada dokter bedah dermatologi juga menemukan bahwa terdapat 9\% dokter yang diancam secara legal oleh klien dengan BDD. ${ }^{41}$ Kelainan BDD juga dikaitkan dengan masalah mental lainnya seperti depresi, gangguan kecemasan sosial, gangguan makan, atau gangguan obsesif kompulsif, dan sering terdiagnosis sebagai salah satu dari gangguan-gangguan tersebut. ${ }^{8}$ Oleh karena itu, deteksi klien dengan BDD pada layanan prosedur estetik menjadi sangat penting dilakukan demi kebaikan klien maupun dokter yang menangani.

\section{Tantangan Tata Laksana BDD pada Layanan Estetik}

Kecenderungan orang dengan BDD untuk mencari layanan prosedur estetik menjadi dasar pentingnya kemampuan mendeteksi BDD oleh dokter di layanan estetik, terutama apabila hendak melakukan tindakan invasif. Delapan puluh empat persen dari dokter anggota American Society for Aesthetic Plastic Surgery (ASAPS) mengatakan bahwa mereka pernah melakukan operasi pada klien dengan BDD yang tidak terdeteksi sebelum prosedur. $^{36}$ Tidak berbeda jauh, penelitian pada komunitas dokter bedah dermatologi juga menemukan bahwa $63 \%$ dokter pernah melakukan tindakan pada klien dengan BDD yang terdiagnosis setelah prosedur. $^{41}$ Suatu penelitian multicenter menunjukkan bahwa dokter hanya dapat mendeteksi 4,7\% dari klien yang terdeteksi BDD dengan alat skrining yakni Body Dysmorphic Disorder Questionnaire (BDDQ). ${ }^{42}$ Survei yang dilakukan oleh ASAPS terhadap anggotanya menemukan bahwa meskipun mayoritas dokter bedah plastik menyadari bahwa ada kemungkinan BDD di antara klien yang mereka tangani, namun angka kejadian yang sebenarnya kemungkinan lebih tinggi dibandingkan ekspektasi mereka. ${ }^{36}$ Penelitian pada dokter layanan estetik (bedah plastik estetik, dermatologi, dan kedokteran estetik) di Belanda juga menunjukkan bahwa meskipun mayoritas dari dokter-dokter tersebut menyadari tentang BDD, namun persentase klien dengan BDD yang mereka laporkan lebih rendah daripada yang sebenarnya. ${ }^{25}$

Saat ini masih terdapat perbedaan pendapat mengenai boleh tidaknya melakukan prosedur estetik pada klien dengan BDD. Survei menunjukkan sebanyak $63 \%$ dokter bedah dermatologi meyakini bahwa BDD adalah kontraindikasi terapi estetik. ${ }^{32}$ Survei lain terhadap 265 dokter bedah plastik estetik memperlihatkan sebanyak $30 \%$ dokter meyakini bahwa BDD selalu merupakan kontraindikasi operasi. ${ }^{36}$ Apabila dibandingkan dengan permintaan layanan estetik lain (seperti dermatologi, dental, atau prosedur lain), permintaan tindakan operasi atau invasif minimal oleh klien dengan BDD lebih cenderung dikabulkan. ${ }^{34}$

Tatalaksana BDD di Layanan Estetik 
Isu BDD di layanan estetik menunjukkan pentingnya dokter bedah estetik melengkapi skrining kesehatan mental untuk semua klien baru. Penilaian ini sangat penting dilakukan karena dua hal, yaitu: (1) membantu menentukan apakah motivasi klien sebelum menjalani tindakan operasi dan ekspektasi terhadap hasil operasi realistis atau tidak, dan (2) mengidentifikasi klien yang memiliki BDD atau kondisi psikiatri lain yang mungkin merupakan kontraindikasi tindakan. ${ }^{16}$ Oleh karena itu penilaian psikologis sebelum tindakan operasi harus berfokus pada beberapa aspek, seperti motivasi dan ekspektasi klien, riwayat serta status psikiatri klien, dan kekhawatiran terhadap penampilan dan citra tubuh (termasuk penilaian gejala BDD). ${ }^{16}$ Dalam hal deteksi dini BDD pada klien layanan estetik, maka penilaian terhadap dua hal terakhir tidak dapat diabaikan.

Riwayat dan status psikiatri klien merupakan informasi penting yang sebaiknya rutin diminta dari klien layanan estetik sebagai bagian dari riwayat medis dan pemeriksaan fisik. Beberapa klien mungkin sungkan untuk melaporkan sendiri riwayat kesehatan mental mereka karena khawatir bahwa pengobatan psikiatri yang pernah atau sedang dilakukan akan menjadi kontraindikasi tindakan estetik, namun hal ini penting untuk ditanyakan ${ }^{16}$ karena sekitar $20 \%$ dari klien bedah estetik memiliki riwayat masalah kesehatan mental, yang jauh lebih tinggi dibandingkan $4 \%$ pada klien bedah plastik non-estetik. ${ }^{43}$ Terdapat 18\% dari klien bedah estetik yang sedang menggunakan obat psikiatri pada saat konsultasi pertama di layanan estetik; lebih tinggi secara signifikan dibandingkan hanya 5\% pada klien bedah non-estetik. ${ }^{43}$ Ditambah lagi, banyak dari klien-klien tersebut yang mendapatkan obat psikiatri dari dokter umum dan bukan psikiater, dan berdasarkan penelitian seringkali dosis obat psikiatri yang diberikan oleh dokter umum adalah dosis subterapeutik. ${ }^{16}$ Oleh karena itu, dalam situasi di mana klien mendapatkan obat psikiatri dari dokter non-psikiater dan dicurigai adanya psikopatologi, maka direkomendasikan untuk klien dikonsultasikan ke profesional kesehatan mental. ${ }^{16}$ Sedangkan untuk klien yang sedang dalam pengobatan psikiatri, klien harus ditanyakan mengenai apakah psikiaternya mengetahui tentang permintaannya untuk mendapatkan tindakan estetik, dan dokter layanan estetik harus mengkonfirmasi ke psikiater yang bersangkutan apakah tindakan estetik yang diajukan klien wajar pada saat tersebut. ${ }^{16}$
Kekhawatiran terhadap penampilan dan citra tubuh merupakan bagian utama dari evaluasi klien. ${ }^{44}$ Klien sebaiknya diminta untuk menyampaikan, dengan bahasa mereka, apa yang mereka tidak sukai dari penampilan mereka. Klien seharusnya dapat menjelaskan kekhawatiran spesifik yang dapat dengan mudah dilihat orang lain. Apabila klien menunjukkan ketidaknyamanan yang nyata akan suatu defek yang tidak mudah dilihat, ada kemungkinan klien tersebut memiliki BDD. Klien yang menyatakan bahwa ia menghabiskan banyak waktu untuk memikirkan masalah penampilannya juga kemungkinan

memiliki BDD. Terkadang klien juga menunjukkan preokupasinya dengan membawa banyak foto artis dengan fitur muka yang diinginkannya, atau foto diri sendiri yang telah dimodifikasi menggunakan pensil atau aplikasi untuk menunjukkan perubahan yang diinginkan. Dokter juga sebaiknya menanyakan bagaimana pengaruh perasaan klien mengenai penampilannya terhadap fungsi sehari-hari, untuk mengetahui derajat keparahan yang mungkin dialami klien. Klien yang memiliki BDD biasanya melaporkan bahwa kekhawatiran terhadap penampilannya mengganggu hubungan kerja, hubungan dengan pasangan, atau aktivitas sehari-hari. Untuk menilai lebih jauh kemungkinan BDD, dokter layanan estetik dapat mempertimbangkan untuk menggunakan salah satu dari beberapa alat skrining BDD yang telah divalidasi. Bila hasil skrining menunjukkan hasil positif, maka klien sebaiknya dirujuk ke psikolog atau psikiater. ${ }^{16}$

Dari sisi legalitas, Sweis dkk (2017) menganjurkan suatu pernyataan resmi yang dibuat sebelum prosedur pada klien yang dicurigai memiliki BDD. Pernyataan ini terdiri dari deskripsi BDD dan lima pernyataan yang ditandatangi klien untuk menandakan persetujuannya terhadap setiap pernyataan tersebut. Lima pernyataan tersebut terdiri dari: (1) Saya belum pernah didiagnosis atau diobati untuk BDD, (2) Saya sudah pernah menjalani prosedur-prosedur bedah plastik di masa lalu, dan saya belum pernah merasa tidak gembira dengan prosedur-prosedur tersebut, (3) Saya mengizinkan untuk menghubungi dokter bedah plastik saya sebelumnya, (4) Saya menyadari ada komponen emosional yang signifikan dalam memilih sebuah prosedur bedah plastik elektif, dan

(5) Saya mengerti bahwa prosedur yang saya cari mungkin tidak memiliki hasil yang persis dengan yang saya inginkan. ${ }^{45}$

Terdapat kemungkinan ada klien yang akan bereaksi terhadap rujukan psikiatri dengan kemarahan, dan bisa juga menolak, dan klien yang 
demikian kemungkinan bukanlah kandidat yang sesuai untuk dilakukan tindakan estetik. Penting bagi dokter layanan estetik untuk memperlakukan rujukan psikiatri seperti layaknya rujukan lainnya dalam rangka membantu mengurangi stigmatisasi profesional kesehatan mental dan meningkatkan penerimaan klien terhadap rujukan tersebut. Rujukan psikiatri juga mungkin diberikan setelah tindakan operasi, pada situasi di mana klien tidak puas terhadap hasil operasi yang dianggap berhasil oleh dokter, ataupun munculnya psikopatologi (seringkali BDD) yang tidak terdeteksi sebelum tindakan dilakukan. ${ }^{16}$

\section{Alat Skrining BDD pada Layanan Estetik}

Baku emas yang digunakan untuk mendiagnosis BDD adalah wawancara terstruktur dengan BDD Structured Clinical Interview for DSM-5 (SCID). ${ }^{46}$ Namun, instrumen ini tidak praktis pada layanan klinis non-psikiatri karena membutuhkan keterampilan khusus dan waktu sekitar 15 menit. Oleh karena itu, saat ini telah dikembangkan beberapa jenis instrumen deteksi dini untuk BDD pada layanan non-psikiatri, baik yang sudah divalidasi maupun yang belum, di antaranya yang paling umum adalah BDDQ (-DV untuk layanan dermatologi), Dysmorphic Concern Questionnaire (DCQ), The Yale-Brown Obsessive-Compulsive Scale Modified for Body Dysmorphic Disorder (BDD-YBOCS), Body Dysmorphic Disorder Examination (BDDE) (-SR untuk self-report), Body Dysmorphic Disorder Symptoms Scale (BDD-SS), Clinical Global Impression Scale (CGI Scale), dan lainnya. ${ }^{13,15,47-52}$ Setiap instrumen ini memiliki kelebihan dan kekurangan masing-masing dalam hal keakuratan dan kemudahan penggunaan. ${ }^{53}$

Kuesioner BDDQ merupakan alat ukur yang telah divalidasi dan membutuhkan waktu singkat (1-2 menit) dengan validitas $91,7 \%$, sensitivitas $100 \%$, dan spesifisitas $90,3 \%$ dibandingkan dengan BDD-SCID ketika diuji di layanan bedah plastik dan rekonstruksi fasial. ${ }^{29}$ Kuesioner BDDQ terdiri dari 5 pertanyaan dengan skor 1 poin untuk setiap pertanyaan, kecuali pertanyaan nomor 5 (pertanyaan untuk mempertimbangkan diagnosis gangguan makan). Skor 4 pada BDDQ setara dengan terpenuhinya seluruh kriteria BDD dan oleh karena itu dikatakan sebagai positif pada skrining BDD. Jawaban untuk pertanyaan nomor 1 dan 2 harus "ya" untuk dapat melanjutkan ke pertanyaan berikutnya. ${ }^{15}$

Dufresne dan Phillips memodifikasi BDDQ menjadi BDDQ-DV untuk digunakan spesifik pada layanan dermatologi, ${ }^{50,54}$ dan telah divalidasi di layanan bedah dermatologi dengan sensitivitas $100 \%$ dan spesifisitas $94,7 \% .{ }^{50}$ BDDQ-DV merupakan kuesioner yang sama dengan BDDQ, namun dengan beberapa modifikasi, yaitu: substitusi respons ya/tidak dengan skala Likert 1-5 untuk mengindikasikan derajat keparahan, dan dihapusnya pertanyaan mengenai dampak kekhawatiran klien akan penampilan dan citra tubuhnya terhadap keluarga atau teman klien. ${ }^{50,54}$ Untuk menyatakan skrining positif BDD, klien harus melaporkan adanya preokupasi dan ketidaknyamanan atau gangguan fungsi dengan setidaknya derajat sedang (skor 3 atau lebih). ${ }^{55}$

Kuesioner DCQ adalah alat ukur skrining psikiatri yang relatif kompleks, berisi beberapa pertanyaan yang bukan merupakan gejala BDD, dan tidak mengukur derajat keparahan atau rentang gejala yang spesifik untuk BDD. Kuesioner DCQ terdiri dari tujuh pertanyaan dengan poin yang berbeda-beda, dan telah divalidasi di layanan dermatologi dengan menggunakan nilai cut-off $\geq 14$ untuk mencapai sensitivitas $72 \%$ dan spesifisitas $90,7 \% .^{53}$

Terdapat banyak alat skrining lain untuk BDD namun alat-alat tersebut belum divalidasi untuk layanan estetik. Di antaranya adalah BDDYBOCS yang merupakan alat ukur berisi 12 pertanyaan yang banyak digunakan di penelitian untuk mengukur derajat keparahan $\mathrm{BDD}$, namun belum diketahui validitasnya untuk skrining klien sebelum melakukan tindakan operasi estetik. Ada juga BDDE yang merupakan alat ukur berupa 34 pertanyaan dengan waktu 30 menit, dan dirancang untuk mengukur kekhawatiran dismorfik pada klien dengan gangguan makan, namun penggunaannya telah berkurang seiring waktu, mungkin karena lebih relevan untuk gangguan makan dibanding BDD serta tidak cocok untuk klien dengan BDD yang lebih berat. Terdapat pula BDD-SS yang digunakan untuk mengukur gejala psikopatologis BDD dan CGI Scale yang digunakan untuk mengukur fungsi klien secara umum dan melihat perkembangan sebelum dan sesudah tindakan operasi. ${ }^{53}$

Dalam proses menentukan perihal dapat dilakukan prosedur estetik atau tidak, penggunaan alat skrining BDD yang sudah tervalidasi di layanan estetik hendaknya diimplementasikan, dan apabila ditemukan kecenderungan adanya BDD, pendekatan multidisiplin sebaiknya dilakukan untuk konfirmasi diagnosis, menentukan penanganan yang dibutuhkan, dan mempertimbangkan perihal dilakukan/tidaknya prosedur estetik yang bersangkutan. ${ }^{32}$ 


\section{Tata Laksana BDD di Layanan Psikiatri}

Prinsip tata laksana BDD adalah mengurangi preokupasi citra tubuh, pola pikir maladaptif, perfeksionisme, dan skema pikir irasional serta mengurangi perilaku kompulsif seperti memeriksa, merias diri, dan perilaku menghindar yang mengikuti preokupasi tersebut. Psikofarmaka pada BDD terdiri dari fluoxetine, clomipramine, dan escitalopram. ${ }^{56-59}$ Fluoxetine terbukti lebih baik dibanding plasebo dalam meningkatkan kualitas hidup dan mengurangi gejala BDD termasuk yang memiliki tilikan buruk dengan dosis rata-rata $20 \mathrm{mg}$ yang diikuti selama 12 minggu. ${ }^{56}$ Clomiperamine juga terbukti meningkatkan kualitas hidup dan mengurangi gejala BDD

dibanding despiramine dengan dosis clomiperamine rata-rata $138 \mathrm{mg}$ yang dipantau

selama 8 minggu. ${ }^{57}$ Escitalopram dapat mengurangi gejala klinis BDD dengan dosis 20$30 \mathrm{mg}$ selama 14 minggu. ${ }^{59,60}$

Terapi kognitif perilaku merupakan modalitas psikofarmaka yang terbukti lebih baik dibanding psikoedukasi atau terapi suportif. Terapi ini berfokus pada perilaku menghindari lingkungan dan pikiran irasional bahwa citra diri seseorang sepenuhnya ditentukan oleh penampilan serta ada persepsi yang merasa penampilan diri sangat jelek dan tidak normal. ${ }^{61-65}$ Terapi dengan modul oleh Wilhelm et al, selama 18-24 minggu, satu jam per sesi, dua kali per minggu dapat menurunkan gejala-gejala ini dan meningkatkan kualitas hidup orang dengan BDD. ${ }^{65}$ Beberapa peneliti mencoba mengaplikasikan terapi melalui internet dan membuktikan bahwa juga dapat mengurangi gejala pada orang dengan BDD dengan lebih praktis. ${ }^{63,66}$

Teknik-teknik yang dilakukan pada terapi tersebut berupa berupaya secara perlahan untuk menghadapi situasi yang memunculkan dorongan kompulsif BDD seperti mengecek penampilan atau menghindar, menghadapi perasaan tidak nyaman tersebut, dan menahan untuk tidak melakukan perilaku. ${ }^{62}$ Psikoedukasi, peningkatan motivasi dengan teknik motivational interviewing, penyusunan kognitif yang lebih adaptif, menahan untuk tidak melihat cermin, dan latihan memfokuskan perhatian juga dapat ditambahkan sesuai dengan kebutuhan pasien masing-masing. ${ }^{62}$ Dukungan keluarga dan orang terdekat juga dapat membantu meningkatkan motivasi, kepatuhan pasien untuk tetap mengikuti terapi psikofarmaka dan non psikofarmaka, serta mengurangi gejala BDD. ${ }^{67}$

\section{Penutup}

Kelainan BDD merupakan masalah kejiwaan yang seringkali tidak terdiagnosis karena mayoritas orang dengan BDD datang ke layanan estetik, yang ditunjukkan dengan lebih tingginya prevalensi BDD di layanan estetik dibandingkan populasi umum. Sayangnya kesadaran akan BDD pada dokter layanan estetik masih rendah dan belum ada kejelasan mengenai BDD sebagai kontraindikasi tindakan operasi, sehingga orang dengan BDD seringkali tidak mendapatkan penanganan yang tepat dan hal ini seringkali berujung pada gugatan legal atau bahkan ancaman fisik terhadap dokter yang melakukan tindakan estetik. Deteksi dini BDD di layanan estetik merupakan langkah awal penatalaksanaan BDD yang dapat dengan mudah dilakukan menggunakan beberapa alat skrining BDD yang telah divalidasi. Dibutuhkan kesadaran dokter layanan estetik akan potensi BDD pada klien dan pentingnya skrining BDD dalam rangka deteksi dini untuk mencegah terjadinya ketidakpuasan klien yang dapat berujung pada masalah legal.

\section{Daftar Pustaka}

1. American Psychiatric Association. Diagnostic and statistical manual of mental disorders [Internet]. 5th ed. 2013. Tersedia pada: https://doi.org/10.1176/appi.books.978089042 5596

2. Grant JE, Phillips KA. Recognizing and treating body dysmorphic disorder. Annals of Clinical Psychiatry. 2005;17(4):205-10.

3. Rief $\mathrm{W}$, Buhlmann $\mathrm{U}$, Wilhelm $\mathrm{S}$, Borkenhagen A, Brähler E. The prevalence of body dysmorphic disorder: a population-based survey. Psychol Med. 2006;36(6):877-85.

4. Koran LM, Abujaoude E, Large MD, Serpe RT. The Prevalence of body dysmorphic disorder in the United States Adult Population. CNS spectr. 2008;13(4):316-22.

5. Schieber K, Kollei I, de Zwaan M, Martin A. Classification of body dysmorphic disorder What is the advantage of the new DSM-5 criteria? Journal of Psychosomatic Research. 2015;78(3):223-7.

6. Veale D, Gledhill LJ, Christodoulou P, Hodsoll J. Body dysmorphic disorder in different settings: A systematic review and estimated weighted prevalence. Body Image. 2016;18:168-86. 
7. Prevalence of BDD [Internet]. BDD. [dikutip 16 Agustus 2021]. Tersedia pada: https://bdd.iocdf.org/professionals/prevalence/

8. Body dysmorphic disorder (BDD) $\mid$ anxiety and depression association of America, ADAA [Internet]. [dikutip 16 Agustus 2021]. Tersedia pada: https://adaa.org/understandinganxiety/body-dysmorphic-disorder

9. Buhlmann U, Glaesmer H, Mewes R, Fama JM, Wilhelm S, Brähler E, dkk. Updates on the prevalence of body dysmorphic disorder: A population-based survey. Psychiatry Research. 2010;178(1):171-5.

10. Faravelli C, Salvatori S, Galassi F, Aiazzi L, Drei C, Cabras P. Epidemiology of somatoform disorders: a community survey in Florence. Soc Psychiatry Psychiatr Epidemiol. 1997;32(1):24-9.

11. Otto MW, Wilhelm S, Cohen LS, Harlow BL. Prevalence of body dysmorphic disorder in a community sample of women. AJP. 2001;158(12):2061-3.

12. Fawcett E, Power H, Fawcett J. Women are at greater risk of OCD than men: A metaanalytic review of OCD prevalence worldwide. J Clin Psychiatry. 2020;81(4).

13. Rosen J, Reiter J. Development of the body dysmorphic disorder examination. Behav Res Ther. 1996;34(9):755-66.

14. Hay SI, Abajobir AA, Abate KH, Abbafati C, Abbas KM, Abd-Allah F, dkk. Global, regional, and national disability-adjusted lifeyears (DALYs) for 333 diseases and injuries and healthy life expectancy (HALE) for 195 countries and territories, 1990-2016: A systematic analysis for the global burden of disease study 2016 . The Lancet. 2017;390(10100):1260-344.

15. Phillips K. The Broken Mirror: Understanding and treating body dysmorphic disorder. 2nd ed. New York: NY: Oxford University Press; 2005.

16. Sarwer DB, Spitzer JC. Body image dysmorphic disorder in persons who undergo aesthetic medical treatments. Aesthetic Surgery Journal. 2012;32(8):999-1009.

17. Himanshu, Kaur A, Kaur A, Singla G. Rising dysmorphia among adolescents: A cause for concern. J Family Med Prim Care. 2020;9(2):567.

18. Fardouly J, Diedrichs PC, Vartanian LR, Halliwell E. Social comparisons on social media: The impact of facebook on young women's body image concerns and mood.

Body Image. 2015;13:38-45.
19. Ryding FC, Kuss DJ. The use of social networking sites, body image dissatisfaction, and body dysmorphic disorder: A systematic review of psychological research. Psychology of Popular Media. 2020;9(4):412-35.

20. Body Dysmorphic Disorder and the Impact of COVID-19 and Quarantine [Internet]. [dikutip 16 Agustus 2021]. Tersedia pada: https://adaa.org/learn-from-us/from-theexperts/blog-posts/professional/bodydysmorphic-disorder-and-impact-covid-19

21. Rice SM, Graber E, Kourosh AS. A pandemic of dysmorphia: "zooming" into the perception of our appearance. Facial Plastic Surgery \& Aesthetic Medicine. 2020;22(6):401-2.

22. Adebayo KO, Gureje O, Nuhu TF. Body dysmorphic disorder in a Nigerian boy presenting as depression: A case report and literature review. Int $\mathrm{J}$ Psychiatry Med. 2012;44(4):367-72.

23. Sündermann O, Wheatley J, Veale D. 'If you have good skin, you are god. If you have bad skin, you are a piece of rubbish'. Mastery of shame and anger in treatment-resistant body dysmorphic disorder: a single case study. tCBT. 2016;9:e13.

24. Van der Meer J, van Rood YR, van der Wee NJ, den Hollander-Gijsman M, van Noorden MS, Giltay EJ, dkk. Prevalence, demographic and clinical characteristics of body dysmorphic disorder among psychiatric outpatients with mood, anxiety or somatoform disorders. Nordic Journal of Psychiatry. 2012;66(4):232-8.

25. Bouman TK, Mulkens S, van der Lei B. Cosmetic professionals' awareness of body dysmorphic disorder. Plastic and Reconstructive Surgery. 2017;139(2):336-42.

26. Phillips KA, Grant J, Siniscalchi J, Albertini RS. Surgical and nonpsychiatric medical treatment of patients with body dysmorphic disorder. Psychosomatics. 2001;42(6):504-10.

27. Crerand CE, Phillips KA, Menard W, Fay C. Nonpsychiatric medical treatment of body dysmorphic disorder. Psychosomatics. 2005;46(6):549-55.

28. Phillips K, McElroy S, Keck Jr P, Pope Jr H, Hudson J. Body dysmorphic disorder: 30 cases of imagined ugliness. Am J Psychiatry. 1993;(150):302-8.

29. Dey JK, Ishii M, Phillis M, Byrne PJ, Boahene KDO, Ishii LE. Body dysmorphic disorder in a facial plastic and reconstructive surgery clinic: measuring prevalence, assessing comorbidities, and validating a feasible 
screening instrument. JAMA Facial Plast Surg. 2015;17(2):137-43.

30. Ribeiro RVE. Prevalence of body dysmorphic disorder in plastic surgery and dermatology patients: a systematic review with metaanalysis. Aesth Plast Surg. 2017;41(4):964-70.

31. Vindigni V, Pavan C, Semenzin M, Gran S, Gambaro F, Marini M, dkk. The importance of recognizing body dysmorphic disorder in cosmetic surgery patients: do our patients need a preoperative psychiatric evaluation? European Journal of Plastic Surgery. 2002;25(6):305-8.

32. Bowyer L, Krebs G, Mataix-Cols D, Veale D, Monzani B. A critical review of cosmetic treatment outcomes in body dysmorphic disorder. Body Image. 2016;19:1-8.

33. McLaughlin JK, Wise TN, Lipworth L. Increased risk of suicide among patients with breast implants: do the epidemiologic data support psychiatric consultation? psychosomatics. 2004;45(4):277-80.

34. Crerand CE, Menard W, Phillips KA. Surgical and minimally invasive cosmetic procedures among persons with body dysmorphic disorder. Annals of Plastic Surgery. 2010;65(1):11-6.

35. Bulut O, Wallner F, Oladokun D, Plinkert P, Baumann I, Hohenberger R. Patients screening positive for body dysmorphic disorder show no significant health-related quality of life gain after functional septorhinoplasty at a tertiary referral center. Facial plast Surg. 2018;34(03):318-24.

36. Sarwer D. Awareness and identification of body dysmorphic disorder by aesthetic surgeons: Results of a survey of american society for aesthetic plastic surgery members. Aesthetic Surgery Journal. 2002;22(6):531-5.

37. Doheny K, Pt A. Cosmetic surgeries don't always end in a smile. Los Angeles Time. 1998;1.

38. Foster D. Looks Could Kill as Face-Lift Patient Gets a Gun : Plastic surgery: Suburban seattle woman shoots her surgeon and herself after complaining of constant pain. The doctor's staff says her problems were psychological, not physical. [Internet]. Los Angeles Times. 1991 [dikutip 16 Agustus 2021]. Tersedia pada: https://www.latimes.com/archives/laxpm-1991-05-05-mn-1991-story.html

39. Chinese man sentenced to death over knife murder of doctor at hospital where he had botched nose job | Daily Mail Online [Internet]. [dikutip 16 Agustus 2021]. Tersedia pada:

https://www.dailymail.co.uk/news/article-

2546928/Chinese-man-sentenced-death-knifemurder-doctor-hospital-botched-nose-job.html

40. Gorney M. Recognition and Management of the Patient Unsuitable for Aesthetic Surgery:

Plastic and Reconstructive Surgery. 2010;126(6):2268-2071.

41. Sarwer DB, Spitzer JC, Sobanko JF, Beer KR. Identification and management of mental health issues by dermatologic surgeons: A Survey of American Society for dermatologic surgery members. Dermatologic Surgery. 2015;41(3):352-7.

42. Joseph AW, Ishii L, Joseph SS, Smith JI, Su P, Bater K, dkk. Prevalence of body dysmorphic disorder and surgeon diagnostic accuracy in facial plastic and oculoplastic surgery clinics. JAMA Facial Plast Surg. 2017;19(4):269-74.

43. Sarwer DB, Zanville HA, LaRossa D, Bartlett SP, Chang B, Low DW, dkk. Mental health histories and psychiatric medication usage among persons who sought cosmetic surgery. Plastic and Reconstructive Surgery. 2004;114(7):1927-33.

44. Sarwer DB. Psychological assessment of cosmetic surgery patients. Dalam: Psychological aspects of reconstructive and plastic surgery: clinical, empirical and ethical perspectives. Philadelphia: Lippincott Williams \& Wilkins; 2006. hlm. 267-83.

45. Sweis IE, Spitz J, Barry DR, Cohen M. A Review of body dysmorphic disorder in aesthetic surgery patients and the legal implications. Aesth Plast Surg. Agustus 2017;41(4):949-54.

46. Osorio F, Loureiro S, Hallak J, JP Machadode-sousa, Ushirohira J, Baes C. Clinical validity and intrarater and test-retest reliability of the structured clinical interview for dsm-5 Clinical Version (SCID-5-CV). Psychiatry and Clinical Neurosciences. 2019;73:754-60.

47. Rosen J, Reiter J. Body dysmorphic disorder examination:selfreport:BDDE-SR.

Burlington VT: Psychology Departement, University of Vermont; 1995.

48. Wilhelm S, Greenberg JL, Rosenfield E, Kasarskis I, Blashill AJ. The body dysmorphic disorder symptom scale: development and preliminary validation of a self-report scale of symptom specific dysfunction. Body Image. Juni 2016;17:82-7.

49. Busner J, Targum S. The Clinical global impressions scale: applying a research tool in clinical practice. Psychiatry. 2007;29-37. 
50. Dufresne RG, Phillips KA, Vittorio CC, Wilkel CS. A Screening questionnaire for body dysmorphic disorder in a cosmetic dermatologic surgery practice. Dermatol Surg. $2001 ; 6$.

51. Oosthuizen P, Lambert T, Castle DJ. Dysmorphic concern: prevalence and associations with clinical variables. Australian and New Zealand Journal of Psychiatry. 1998;32:129-32.

52. Phillips K, Hollander E, Rasmussen S, Aronowitz B, DeCaria C, Goodman W. A severity rating scale for body dysmorphic disorder: development, reliability, and validity of a modified version of the Yale-Brown

Obsessive Compulsive Scale.

Psychopharmacol Bull. 1997;33(1):17-22.

53. Higgins S, Wysong A. Cosmetic surgery and body dysmorphic disorder - an update.

InternationalJournalofWomen's

Dermatology. Maret 2018;4(1):43-8.

54. Phillips KA, Dufresne RG, Wilkel CS, Vittorio CC. Rate of body dysmorphic disorder in dermatology patients. Journal of the American Academy of Dermatology. 2000;42(3):436- 41.

55. Danesh M, Beroukhim K, Bs CN, Levin E, Koo J. Body dysmorphic disorder screening tools for the dermatologist: Systematic review. Practical dermatology. Februari 2015;4.

56. Phillips KA, Albertini RS, Rasmussen SA. A Randomized placebo-controlled trial of fluoxetine in body dysmorphic disorder. Arch Gen Psychiatry. 2002;59(4):381.

57. Hollander E, Allen A, Kwon J, Aronowitz B, Schmeidler J, Wong C, dkk. Clomipramine vs desipramine crossover trial in body dysmorphic disorder: Selective efficacy of a serotonin reuptake inhibitor in imagined ugliness. Arch Gen Psychiatry. 1999;56(11):1033.

58. Ipser JC, Sander C, Stein DJ.

Pharmacotherapy and psychotherapy for body dysmorphic disorder. Cochrane Common Mental Disorders Group, editor. Cochrane Database of Systematic Reviews [Internet]. 21 Januari 2009 [dikutip 12 Agustus 2021];

Tersedia pada: https://doi.wiley.com/10.1002/14651858.CD0 05332.pub2

59. Phillips KA, Keshaviah A, Dougherty DD, Stout RL, Menard W, Wilhelm S.
Pharmacotherapy relapse prevention in body dysmorphic disorder: A double-blind, placebocontrolled trial. AJP. 2016;173(9):887-95.

60. Fang A, Porth R, Phillips KA, Wilhelm S. Personality as a predictor of treatment response to escitalopram in adults with body dysmorphic disorder: Journal of Psychiatric Practice. 2019;25(5):347-57.

61. Enander J, Andersson E, Mataix-Cols D, Lichtenstein L, Alström K, Andersson G, dkk. Therapist guided internet based cognitive behavioural therapy for body dysmorphic disorder: single blind randomised controlled trial. BMJ. 2016;i241.

62. Fang A, Steketee G, Keshaviah A, Didie E, Phillips KA, Wilhelm S. Mechanisms of change in cognitive behavioral therapy for body dysmorphic disorder. Cogn Ther Res. 2020;44(3):596-610.

63. Gentile AJ, La Lima C, Flygare O, Enander J, Wilhelm S, Mataix-Cols D, dkk. Internet-based, therapist-guided, cognitive-behavioural therapy for body dysmorphic disorder with global eligibility for inclusion: an uncontrolled pilot study. BMJ Open. 2019;9(3):e024693.

64. Enander J, Ljótsson B, Anderhell L, Runeborg M, Flygare O, Cottman O, dkk. Long-term outcome of therapist-guided internet-based cognitive behavioural therapy for body

dysmorphic disorder (BDD-NET): a naturalistic 2-year follow-up after a randomised controlled trial. BMJ Open. 2019;9(1):e024307.

65. Wilhelm S, Phillips KA, Fama JM, Greenberg JL, Steketee G. Modular cognitive-behavioral therapy for body dysmorphic disorder. Behavior Therapy. 2011;42(4):624-33.

66. Hartmann AS, Schmidt M, Staufenbiel T, Ebert DD, Martin A, Schoenenberg K. Imagin youth - a therapist-guided internet-based cognitive-behavioral program for adolescents and young adults with body dysmorphic disorder: Study protocol for a two-arm randomized controlled trial. Front Psychiatry. 2021;12:682965.

67. Marques L, Weingarden HM, LeBlanc NJ, Siev J, Wilhelm S. The relationship between perceived social support and severity of body dysmorphic disorder symptoms: the role of gender. Braz J Psychiatry. 2011;33(3):238-44. 